\title{
Natural Drying and Chemical Characteristics of Hybrid Poplar Firewood Produced from Agricultural Bioenergy Buffers in Southern Québec, Canada
}

\author{
Julien Fortier $^{1, * D}$, Benoit Truax ${ }^{1}$, Daniel Gagnon ${ }^{1,2}$ and France Lambert ${ }^{1}$ \\ 1 Fiducie de Recherche sur la Forêt des Cantons-de-l'Est/Eastern Townships Forest Research Trust, \\ 1 rue Principale, Saint-Benoît-du-Lac, QC J0B 2M0, Canada; btruax@frfce.qc.ca (B.T.); \\ daniel.gagnon@uregina.ca (D.G.); france.lambert@frfce.qc.ca (F.L.) \\ 2 Department of Biology, University of Regina, 3737 Wascana Parkway, Regina, SK S4S 0A2, Canada \\ * Correspondence: fortier.ju@gmail.com
}

Citation: Fortier, J.; Truax, B.; Gagnon, D.; Lambert, F. Natural Drying and Chemical Characteristics of Hybrid Poplar Firewood Produced from Agricultural Bioenergy Buffers in Southern Québec, Canada. Forests 2021, 12, 122. https://doi.org/ 10.3390/f12020122

Academic Editors: Ronald S. Zalesny and Andrej Pilipović

Received: 14 December 2020

Accepted: 20 January 2021

Published: 23 January 2021

Publisher's Note: MDPI stays neutral with regard to jurisdictional claims in published maps and institutional affiliations.

Copyright: (c) 2021 by the authors. Licensee MDPI, Basel, Switzerland. This article is an open access article distributed under the terms and conditions of the Creative Commons Attribution (CC BY) license (https:/ / creativecommons.org/licenses/by/ $4.0 /)$.

\begin{abstract}
Implementing bioenergy buffers on farmland using fast-growing tree species could reduce firewood harvest pressure in woodlots and increase forest connectivity, while improving carbon sequestration, phytoremediation, stream habitats, soil stabilization and hydrological regulation. The objective of the study was to evaluate the natural drying and chemical characteristics of hybrid poplar firewood produced from bioenergy buffers, and to compare these characteristics with those of native species harvested in adjacent woodlots. In Trial A, $110 \mathrm{~cm}$-long unsplit logs (a feedstock for biomass furnaces) were produced to evaluate the effect of log diameter class on firewood quality. In this trial, hybrid poplar firewood characteristics were also compared with Populus tremuloides, Acer rubrum and Fraxinus americana. In Trial B, the effect of hybrid poplar genotype and cover treatment was evaluated on the moisture content of short split logs (40 cm long). Firewood of satisfactory quality was produced on a yearly cycle for short split logs, and on a biannual cycle for long unsplit logs. Covering short split log cords with metal sheeting lowered the final moisture content (from $20.7 \%$ to $17.3 \%$ ) and reduced its variability, while genotype did not significantly affect final moisture content. In Trial A, larger-diameter logs from hybrid poplar had lower element concentrations, but slightly higher moisture content after two years. A two-fold variation in $\mathrm{N}$ concentration was observed between diameter classes, suggesting that burning larger poplar logs would minimize atmospheric $\mathrm{N}$ pollution. Heating value, carbon and calcium concentrations increased following the seasoning of hybrid poplar firewood. After the first seasoning year outdoors, hybrid poplar had the highest moisture content (33.1\%) compared to native species (24.1-29.5\%). However, after the second seasoning year in an unheated warehouse, the opposite was observed (14.3\% for hybrid poplar vs. $15.0-21.5 \%$ for native species). Heating value, carbon and nitrogen concentrations were similar between tree species, while high phosphorus and base cation concentrations characterized hybrid poplar, suggesting higher ash production. Poplar bioenergy buffers could provide a complementary source of firewood for heating in the fall and in the spring, when the heat demand is lower than during cold winter months.
\end{abstract}

Keywords: fuelwood; seasoning; log diameter; splitting; heating value; moisture content; agroforestry; red maple; white ash; trembling aspen

\section{Introduction}

Compared to wood chip or pellet production, firewood requires little processing and equipment, and is typically seasoned outdoors [1]. It is therefore an attractive solid biofuel for private landowners and farmers, as it can be produced at low cost. On private forestland and farmland of Northeastern America, most bioenergy feedstock comes from firewood that is harvested in woodlots, and very little land area is dedicated to bioenergy plantations of fast-growing woody species [2-4]. Because several hardwood species (birches, maples, 
ashes, beech, oaks, etc.) are locally abundant, deciduous species with a low wood density such as poplars (Populus sp.) are often disregarded as a source of firewood.

In regions where agriculture dominates the landscape, rural communities are more than ever facing major environmental challenges related to water quality decline, stream habitat protection, forest habitat loss and fragmentation, and climate change [5-7]. The large-scale implementation of bioenergy buffers along agricultural riparian zones, and field margins could be a solution to rapidly address these challenges, as it would reduce firewood harvesting pressure in woodlots and increase forest patch connectivity, while creating opportunities for carbon sequestration, agricultural pollutants removal, stream habitat improvement and hydrological regulation [8-13]. In Northeastern America, hybrid poplars (Populus $\times$ spp.) are especially promising for the design of bioenergy buffers, as they create a forest canopy within a decade, and provide high woody biomass yields even on more marginal land $[9,14,15]$. In this context, it is important to validate that firewood of satisfactory quality can be produced in hybrid poplar buffers in order to stimulate their adoption by the farming community.

Moisture content of seasoned firewood is negatively linked to the amount of heat produced during combustion [16]. Consequently, when moisture content of firewood is low, less feedstock is needed for heating, which reduces wood burning impacts on greenhouse gases and on the thermal load to the atmosphere [17]. The combustion of inadequately seasoned wood also increases creosote accumulation in chimneys and the release of air pollutants (fine particles from smoke, carbon monoxide, benzene, formaldehyde and polycyclic aromatic hydrocarbons), which creates safety and health issues $[18,19]$. In North America, targeted moisture content for seasoned firewood is generally $20 \%$ or less on a wet weight basis [19]. Short split logs ( $\pm 30-40 \mathrm{~cm}$ in length), used in wood stoves or small wood furnaces, usually dry within a year when seasoned adequately [18]. However, more and more houses and farm buildings are now equipped with large biomass furnaces that burn longer wood logs (i.e., $100-150 \mathrm{~cm}$ of length), the seasoning of which generally takes two years under a cold temperate climate (A. Couture, Sequoia Industries, pers. comm.). Very few studies have measured the moisture content of different log sizes from hybrid poplars during seasoning. Studies carried out in Italy have shown little effect of log size on moisture content loss of $P$. deltoides $\times P$. nigra $[1,20]$, which contrasted with conclusions reached in Oregon, United States [21]. Generally, the drying rate of fuelwood decreases as $\log$ diameter or length increase $[18,22]$. Covering the top of firewood piles during outdoor seasoning has also been recommended to lower the moisture content of hardwood and softwood species $[18,23]$.

Energy content (i.e., heating value) is another important characteristic of firewood. Minor variations in heating values are generally observed between tree species, but softwood species tend to have slightly higher heating values than hardwoods due to their higher concentration in extractives and lignin [16]. There is also evidence of both positive and negative changes in the heating value of woody biomass during seasoning [16,24]. However, no studies have measured heating value variations of poplar firewood during seasoning, nor the effect of log size on the properties of this fuelwood.

Elemental characterization of biomass can provide information about the potential environmental and operational impact of feedstock. During combustion, biomass nitrogen (N) can be transformed into nitric oxides, and nitrous oxide to a lesser extent [25]. Both of these gases deplete the ozone layer, while nitric oxides and nitrous oxide respectively contribute to acid rain depositions and global warming [26,27]. Sulphur oxide production, which also increases acid rain, is generally limited during woody biomass combustion, as most sulphur is embedded in the ashes [25]. However, alkali metals can react with sulphate or chlorine, and lead to the formation of salts that cause fouling, slagging and corrosion problems in combustion appliances [25]. Moreover, biomass with high nutrient content leads to higher ash production, which increases the frequency of equipment maintenance [25]. Generally, macronutrient concentrations in the stem of hybrid poplars tend to be high compared to other tree species [28]. There is also a general decline in the 
concentration of most macronutrients as tree stem diameter increases [29], which suggests that producing wood logs of larger diameters would improve the elemental properties of firewood. Finally, significant nutrient leaching from woody biomass piles can occur during outdoor seasoning, but changes in elemental composition of woody biomass during seasoning have rarely been studied [16].

In this study, we measured the natural drying and chemical characteristics of hybrid poplar firewood produced from bioenergy buffers located on farmland in southern Québec, Eastern Canada (Köppen climate zone Dfb, i.e., warm-summer humid continental climate). In a first trial, $110 \mathrm{~cm}$-long unsplit wood logs were produced from hybrid poplar bioenergy buffers (genotype DN $\times$ M-915508), but also from native species harvested from adjacent woodlots (trembling aspen, Populus temuloides Michx., red maple, Acer rubrum L., and white ash, Fraxinus americana L.). These firewood logs were seasoned outdoors for a year, and indoors in an unheated warehouse for another year. Their moisture content (wet weight basis) was sampled at the end of each year. Hybrid poplar logs were separated into three diameter classes, and chemical characteristics of hybrid poplar biomass were measured at harvest and one year after outdoor seasoning. At the end of the first year of outdoor drying, the chemical characteristics of native species were also compared to those of hybrid poplars. In a second trial, we measured, after one year of outdoor seasoning, the effects of hybrid poplar genotype and firewood cover treatment on the moisture content of $40 \mathrm{~cm}$-long split logs.

\section{Materials and Methods}

\subsection{Site Description}

This study took place in the municipality of St-Benoit-du-Lac, a 216-ha property owned by a Benedictine monastic community and located in the Estrie region of southern Québec, Eastern Canada $\left(45^{\circ} 10^{\prime} \mathrm{N} ; 72^{\circ} 16^{\prime} \mathrm{W}\right)$. In 2011, 15 m-wide bioenergy buffers were planted (1666 trees $/$ ha) with three hybrid polar genotypes $(\mathrm{DN} \times \mathrm{M}-915508, \mathrm{D} \times \mathrm{N}-3570$, $\mathrm{M} \times \mathrm{B}-915311$ ), downslope of 45 ha of hayfields. These multifunctional buffers were established with the objective of reducing non-point source pollution from upslope fields, increasing carbon sequestration and producing firewood for the biomass furnaces that provide heat to the Abbey buildings. After eight years, the firewood volume production capacity of the bioenergy buffers ranged from 20.5-29.3 $\mathrm{m}^{3} / \mathrm{ha} / \mathrm{yr}$, depending on genotype, planting stock type and deer protection treatments [9].

\subsection{Firewood Harvesting, Processing and Sampling}

\subsubsection{Trial A-110 cm Long Unsplit Wood Logs}

From 7-14 November 2017, a total of 110 hybrid poplar trees were harvested from 7-year-old bioenergy buffers located along different cultivated fields. Trees from genotype DN $\times$ M-915508 were cut into $\log$ sections of $110 \mathrm{~cm}$, which is the log dimension required for burning in the Abbey biomass furnaces. Wood logs were separated into three different diameter classes: (1) small end diameter $\geq 13 \mathrm{~cm}$; (2) small end diameter between $8 \mathrm{~cm}$ and $12.9 \mathrm{~cm}$; and (3) small end diameter between $3 \mathrm{~cm}$ and $7.9 \mathrm{~cm}$. On 15 November 2017, poplar logs were stacked into metal racks that were designed to be directly inserted into the furnaces (Figure 1). Log piles in metal racks were $\pm 80 \mathrm{~cm}$ wide by $\pm 135 \mathrm{~cm}$ in height. For diameter classes 1 and 2, five metal racks were prepared, while only two racks were prepared for diameter class 3 . 

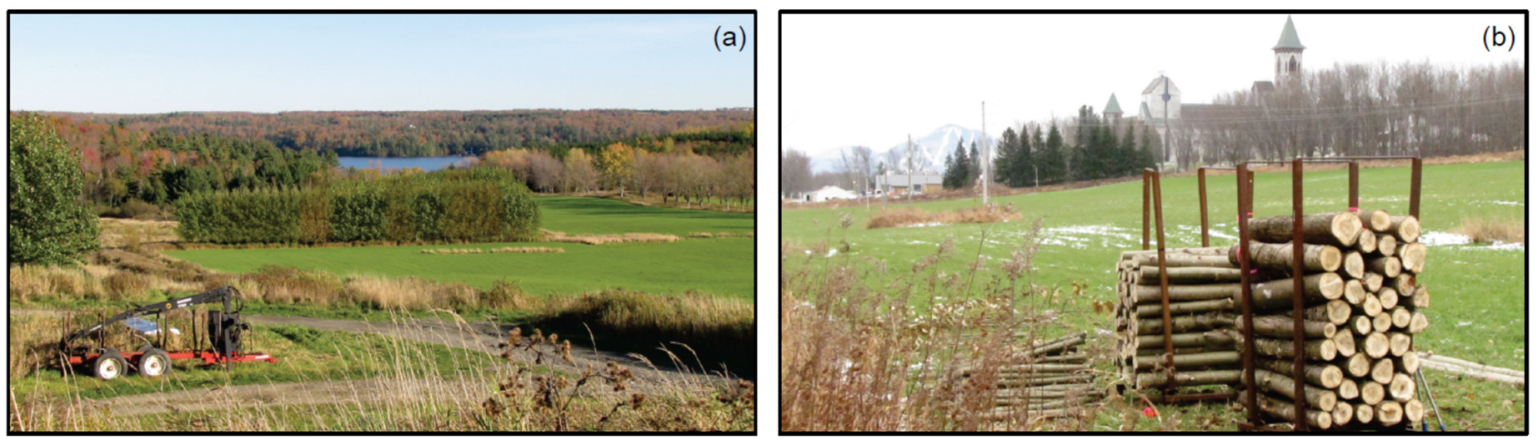

Figure 1. (a) 7-year-old bioenergy buffers located downslope of hayfields; (b) Hybrid poplar firewood log stacking in metal racks according to the different diameter classes. At the end of the study, firewood logs were used to heat the St-Benoît-du-Lac Abbey buildings.

During the same period, native deciduous species growing in woodlots adjacent to the hayfields were also felled and processed into $110 \mathrm{~cm}$ wood logs that were stacked in the same metal racks used for hybrid poplars. Three to four trees from trembling aspen (Populus tremuloides), red maple (Acer rubrum) and white ash (Fraxinus americana) were felled and processed, which produced one metal rack of stacked logs from each species. The mean age of the felled trees was determined by a ring count on a representative tree from each species: 36 years for trembling aspen; 34 years for red maple; and 47 years for white ash.

On 16 November 2017, wood logs staked in metal racks were placed along a gravel road bordering an open field, with log ends being positioned parallel to the dominant winds. No cover was put on racks, and wood logs were left outdoors for almost year (until 4 November 2018). Wood log racks were then placed in an unheated warehouse for another year, prior to being used as feedstocks for the Abbey.

On 14 November 2017, six hybrid poplar logs were sampled (wood disc $\pm 2.5 \mathrm{~cm}$ thick taken with a chainsaw) from each diameter class to determine initial chemical characteristics. Due to unfavorable weather conditions during tree felling, the initial moisture content of wood logs was not measured, but was estimated from data in Trial B for the case of hybrid poplar and from the literature for the native deciduous species. On 6 November 2018, after approximately one year of seasoning outdoors, hybrid poplar and native deciduous species logs were sampled for moisture content and wood chemistry. Wood discs were collected halfway between the middle and the endpoint of logs. For each log sampled, two discs were collected, one that was immediately weighed $( \pm 0.1 \mathrm{~g})$ and another one for chemical analyses. Six logs per diameter classes were sampled for hybrid poplar, and six logs were sampled for the native species (aspen, maple and ash). On 22 October 2019, after approximately two years of seasoning, only moisture content was sampled using the procedure mentioned above. Ten logs per diameter class were sampled for hybrid poplar, and $10 \operatorname{logs}$ were sampled for the native species.

Sampled logs were taken from different positions in metal racks and covered a wide range of diameters. The midpoint diameter of all sampled logs was recorded using perpendicular caliper measurements. Log subsamples were put in paper bags and taken to the lab, where they were air-dried for two months. The subsamples that were fresh-weighed during sampling were then oven-dried $\left(95^{\circ} \mathrm{C}\right)$ until a constant mass was reached (after $\left.24 \mathrm{~h}\right)$, and immediately weighed once out of the oven. The moisture content of logs was calculated on a wet weight basis: Moisture content $(\%)=($ Weight of water $/$ Total weight $) \times 100$.

\subsubsection{Trial B- $40 \mathrm{~cm}$ Long Split Wood Log}

From 5-9 November 2018, a total of 39 hybrid poplar trees were harvested from 8-yearold bioenergy buffers located along different cultivated fields. Twenty trees from genotype $\mathrm{D} \times \mathrm{N}-3570$ and 19 trees from genotype $\mathrm{M} \times \mathrm{B}-915311$ were felled. Depending on tree size, two to four subsamples (stem discs) per tree were taken along different stem sections 
(see Truax et al. [9] for additional details). Stem wood subsamples were immediately fresh-weighed in the field. The subsamples were put in paper bags and taken to the lab, where they were air-dried for two months. The subsamples were then oven-dried $\left(95^{\circ} \mathrm{C}\right)$ until a constant mass was reached (after $24 \mathrm{~h}$ ) and immediately weighed. This allows measurements of moisture content of freshly harvested hybrid poplars.

The 39 felled hybrid poplars were cut into $80 \mathrm{~cm}$-long sections. Logs were stacked on wood poles and left at the buffer's margins until spring. On 22 May 2019, hybrid poplar logs were collected and cut into smaller logs (40 cm in length), which are typically used in wood stoves or small biomass furnaces. Logs were then manually split with an axe, except for the small diameter logs. On 23 May 2019, logs were stacked bark side up to form four wood cords $( \pm 240 \mathrm{~cm}$ long $\times 120 \mathrm{~cm}$ of height $\times 40 \mathrm{~cm}$ wide): two cords per genotype, with one cord per genotype being covered with a roofing metal sheet. Cords were stacked on wood posts in a well-aerated gravel parking lot with full sunlight exposure. On 22 October 2019, 16 split logs of various sizes were collected from each genotype $\times$ cover treatment at different positions in the cords and brought to the lab. Only logs split into two pieces were selected for subsampling. On 24 October 2019, a subsample (i.e., a wood slice $\pm 2.5 \mathrm{~cm}$ thick) from each log was taken in the middle of the $\log$ and immediately weighed fresh. The subsamples were then oven-dried $\left(95^{\circ} \mathrm{C}\right)$ until a constant mass was reached (after $24 \mathrm{~h}$ ), and immediately weighed once out of the oven. Moisture content of logs was calculated on a wet weight basis. A summary of key dates related to firewood processing and sampling is presented in Table 1 for both trials.

Table 1. A summary of key dates related to firewood processing and sampling for Trials A and B.

\begin{tabular}{|c|c|}
\hline $\begin{array}{c}\text { Trial A-Unsplit } 110 \mathrm{~cm} \text { Long Logs } \\
\text { (Hybrid Poplar, Trembling Aspen, Red Maple, White Ash) }\end{array}$ & Dates \\
\hline Tree felling and log processing & 7-14 November 2017 \\
\hline Log stacking in metal racks & 14 November 2017 \\
\hline Outdoor seasoning & 14 November 2017-4 November 2018 \\
\hline Warehouse seasoning (unheated) & 4 November 2018-22 October 2019 \\
\hline Chemistry sampling (fresh, hybrid poplar only) & 7-14 November 2017 \\
\hline Chemistry and moisture sampling (after 1 year, 4 species) & 6 November 2018 \\
\hline Moisture sampling (after 2 years, 4 species) & 22 October 2019 \\
\hline $\begin{array}{c}\text { Trial B-Split } 40 \mathrm{~cm} \text { Long Logs } \\
\text { (2 Hybrid Poplar Genotypes } \times 2 \text { Cover Treatments) }\end{array}$ & Dates \\
\hline Tree felling and moisture sampling & 5-9 November 2018 \\
\hline Log processing and splitting & 22 May 2019 \\
\hline Log stacking & 23 May 2019 \\
\hline Outdoor seasoning & 5-9 November 2018-22 October 2019 \\
\hline Moisture sampling (after 1 year) & 22 October 2019 \\
\hline
\end{tabular}

\subsection{Meteorological Data during the Trials}

A continental moderate-subhumid climate characterizes the study site [30], and more generally, the southern Québec region belongs to the Köppen climate zone Dfb (warmsummer humid continental climate). For the duration of the study, average monthly temperatures and total precipitations are presented in Figure 2, along with 30 years climatic normals (1981-2010). Meteorological data were obtained from the nearest meteorological station of Magog [31,32]. 

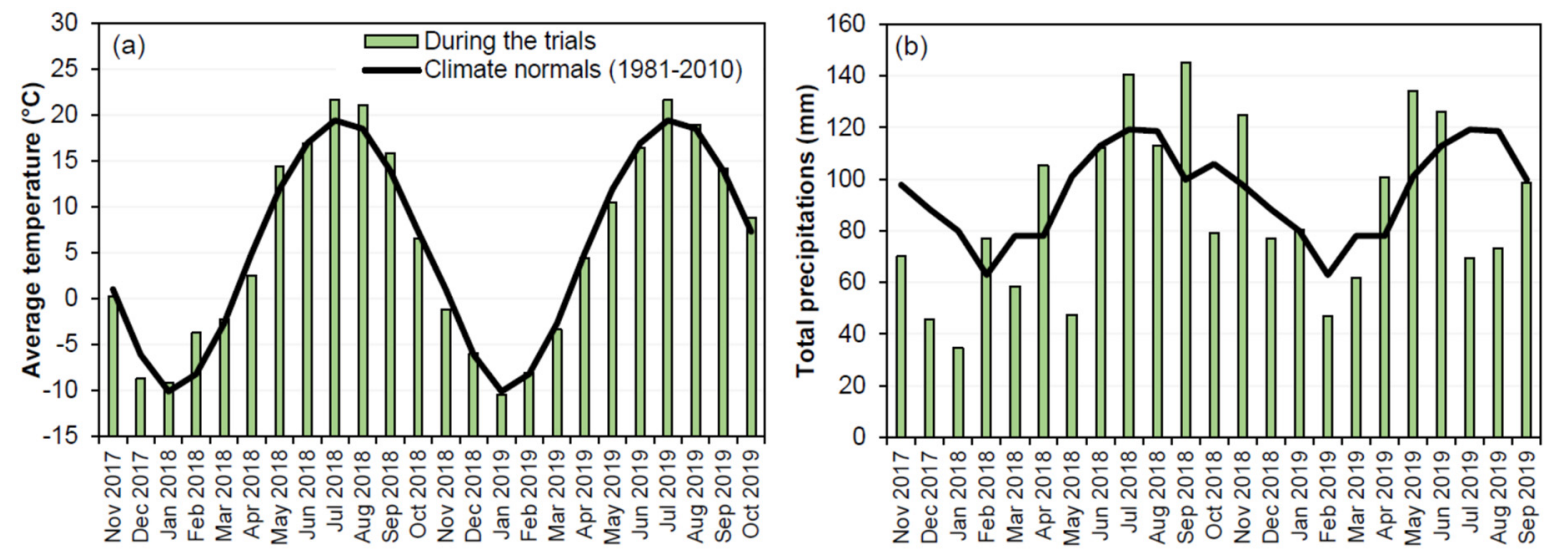

Figure 2. (a) Average monthly temperatures; and (b) total monthly precipitations during the firewood seasoning trials in comparison to 30 years climatic normals. Data were taken from the nearest meteorological station (Magog, QC, Canada). Precipitation data for October 2019 are not shown because an extreme rain event occurred on 31 October (79 mm) after the last moisture content sampling in Trial B (22 October 2019).

\subsection{Chemical Analyses of Firewood}

Firewood subsamples used for chemical analyses were oven-dried at $65^{\circ} \mathrm{C}$ and ground in a mill (Pulverisette 15, Fritsch, Idar-Oberstein, Germany) to a particle size of $<0.5 \mathrm{~mm}$. $\mathrm{C}, \mathrm{N}$ and $\mathrm{S}$ concentrations were determined by the analytic lab of the Institut des Sciences de la Forêt Tempérée (ISFORT) in Ripon (QC, Canada), with a TruMac CNS analyzer (LECO corporation, MI, USA). P, K, Ca and Mg concentrations and lower heating value (LHV) of woody biomass samples were analyzed by the Centre Technologique des Résidus Industriels (CTRI) in Rouyn-Noranda (QC, Canada). A microwave plasma atomic emission spectrometer (4200 MP-AES, Agilent Technologies, Santa Clara, CA, USA) was used for $\mathrm{P}, \mathrm{K}, \mathrm{Ca}$ and $\mathrm{Mg}$ concentration determination, and a bomb calorimeter (6400 Calorimeter, Parr Instrument Company, Moline, IL, USA) was used to determine the LHV of firewood samples on a dry weight basis.

\subsection{Statistical Analyses}

\subsubsection{Trial A}

The dataset related to hybrid poplar firewood was first analyzed using a one-way analysis of variance (ANOVA) to test the effect of diameter class on firewood characteristics (chemistry at harvest and after one year, and moisture content after one year and two years). $n=6$ per diameter class for all variables, except for moisture content after two years ( $n=10$ per diameter class). A two-way ANOVA was used to test the effect of diameter class and drying treatment (freshly harvested vs. one year of drying) and the interaction effect on firewood chemistry ( 6 logs per diameter class $\times 3$ diameter classes $\times 2$ drying treatments). Following all ANOVAs, the normality of residuals distribution was verified using the Shapiro-Wilk W-test $(p<0.05)$, skewness $(<|1|)$ and kurtosis $(<|1|)$. A few transformations were done to meet this assumption, and ANOVAs were rerun. For the one-way ANOVA, a reciprocal transformation was done on firewood moisture content data after two years, while for the two-way ANOVA, a logarithmic (ln) transformation was done on firewood $\mathrm{S}$ and $\mathrm{P}$ concentrations [33].

For the dataset related to firewood characteristics of hybrid poplar and the three native species, a one-way ANOVA was used to test the effect of tree species on firewood characteristics after one and two years of drying. Observations from the $3.0-7.9 \mathrm{~cm}$ diameter class for hybrid poplar were removed from the data set, as wood logs of such a diameter were almost absent for the other species. In the final dataset analyzed, there was no significant species effect on wood log diameter sampled after one year $(p=0.96)$, and after two years of drying $(p=0.83)$. To meet the assumption of normality in residuals distribution, a reciprocal transformation was done on firewood moisture content data 
after two years of drying, and a logarithmic (ln) transformation was done on firewood $P$ concentration after one year of drying. Because sample size was unequal between the four tree species $(n=12$ and 20 for hybrid poplar and $n=6$ and 10 for the other species for firewood characteristics measured after one year and two years of drying respectively), Tukey's HSD test $(\alpha=0.05)$ was used as a means separation procedure [34].

A correlation analysis, using linear least square regressions, was also done to explore potential relationships between firewood log diameter and moisture content or chemical characteristics. After graphical exploration of the data, non-linear trends were observed for the relationships between wood log diameter and elemental concentrations. Choice of the final relationships presented was made on the basis of highest fit (i.e., $R^{2}$ ) and normality in residuals distribution (Shapiro-Wilk W-test).

\subsubsection{Trial B}

A one-way ANOVA was used to test the effect of hybrid poplar genotype on initial moisture content of harvested trees $(n=20$ for genotype $\mathrm{D} \times \mathrm{N}-3570$ and $n=19$ for genotype $\mathrm{M} \times \mathrm{B}-915311)$. A two-way ANOVA was used to test the effect of hybrid poplar genotype and firewood cover treatment (uncovered vs. covered), and the interaction effect between those factors on the final moisture content of split logs $(n=64,16$ logs per genotype per treatment $\times 2$ genotypes $\times 2$ treatments). Given that the Shapiro-Wilk $W$-test is often inappropriate for testing residuals normality for larger sample sizes $(n>50)$ [35], we used normal quantile-quantile plots (Q-Q plots) as a diagnostic tool for verifying normality of residuals distribution [36]. Two outliers (extreme values) were detected in the uncovered treatment for genotype $\mathrm{D} \times \mathrm{N}-3570$. Outliers were removed from the data set, and the ANOVA was rerun. Given that the significance of tested effects was the same between the ANOVAs with and without the outliers, results from the dataset containing the outliers are presented. All statistical analyses were done using JMP (version 11) from SAS Institute (Cary, NC, USA).

\section{Results}

\subsection{Trial $A$}

For hybrid poplar unsplit firewood logs $(110 \mathrm{~cm}$ long), a significant diameter class effect was observed on moisture content after one year $(p<0.001)$ and two years $(p=0.004)$ of drying, with a decreasing moisture content being observed for the smaller diameter logs (Figure 3a). Moisture content differences between logs from different diameter classes were also much larger after one year of drying outdoors (ranging $38.5 \%$ to $26.0 \%$ between diameter classes) than after the second year, where seasoning took place in an unheated warehouse (ranging $15.4 \%$ to $12.7 \%$ between diameter classes). Those trends were reflected in the slope of the linear relationships between wood log diameter and moisture content after one and two years of drying (Figure 4a).

Across the four species, hybrid poplar firewood logs had the highest moisture content after one year of drying, followed by trembling aspen, red maple and white ash (Figure $3 b$ ). A very different pattern was observed after two years of drying, since hybrid poplar was the species with the lowest moisture content $(14.3 \%)$, and white ash had the highest moisture content $(21.5 \%)$. However, the moisture contents of trembling aspen and red maple were not statistically different from the moisture content of hybrid poplar after two years of drying. For trembling aspen and red maple, there were also strong positive linear relationships between wood log diameter and moisture content after one year and two years of drying (Figure $4 b, c)$, while no significant relationship was observed for white ash. 

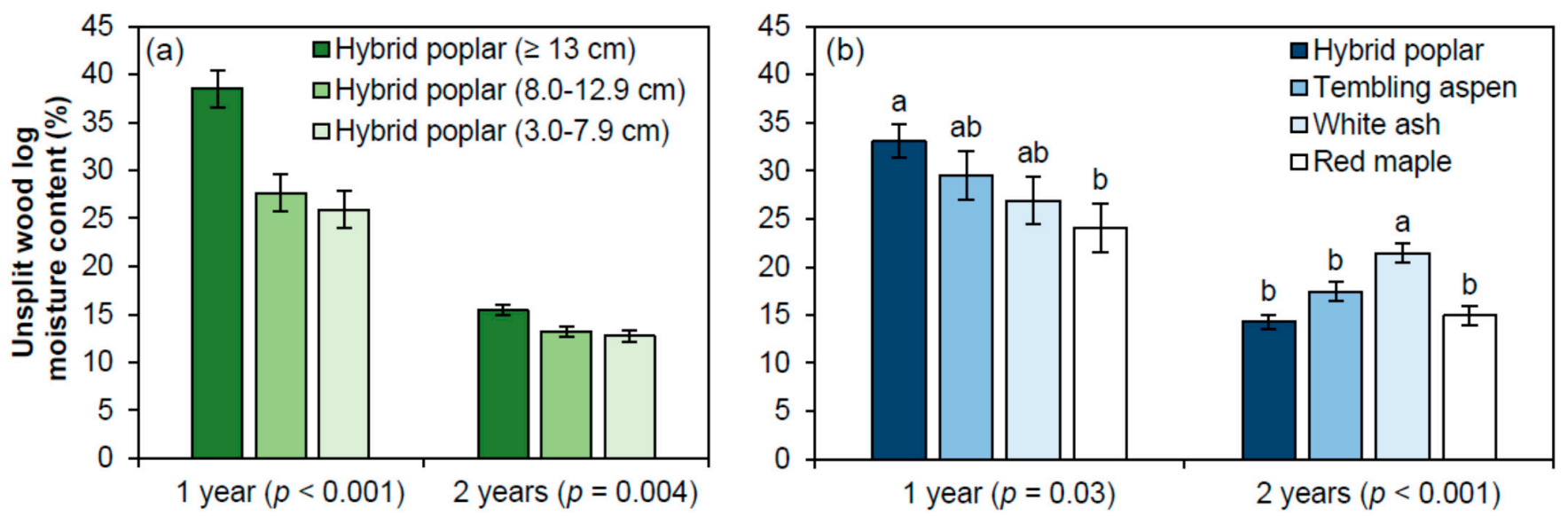

Figure 3. (a) Diameter class effect on the moisture content of unsplit hybrid poplar firewood logs (110 cm in length) after one year and two years of drying (genotype DN $\times$ M-915508); (b) Tree species effect on the moisture content of unsplit firewood logs (110 cm in length) after one and two years of drying. In panel (b), means with different letters are significantly different ( $\alpha=0.05$; Tukey's HSD test). Vertical bars represent the standard error of the mean. During the first year, wood logs were stored outdoors in an open field with no protection from precipitation. During the second year, wood logs were stored in an unheated warehouse. Moisture content at harvest is in the order of 59\% for P. maximowiczii hybrids (see Figure 6 legend), $62 \%$ for trembling aspen, $41 \%$ for red maple and $31 \%$ for white ash [16]. To allow proper comparison of hybrid poplar with native species (panel b), the 3.0-7.9 cm diameter class was removed from the hybrid poplar data set (see Section 2.5.1).
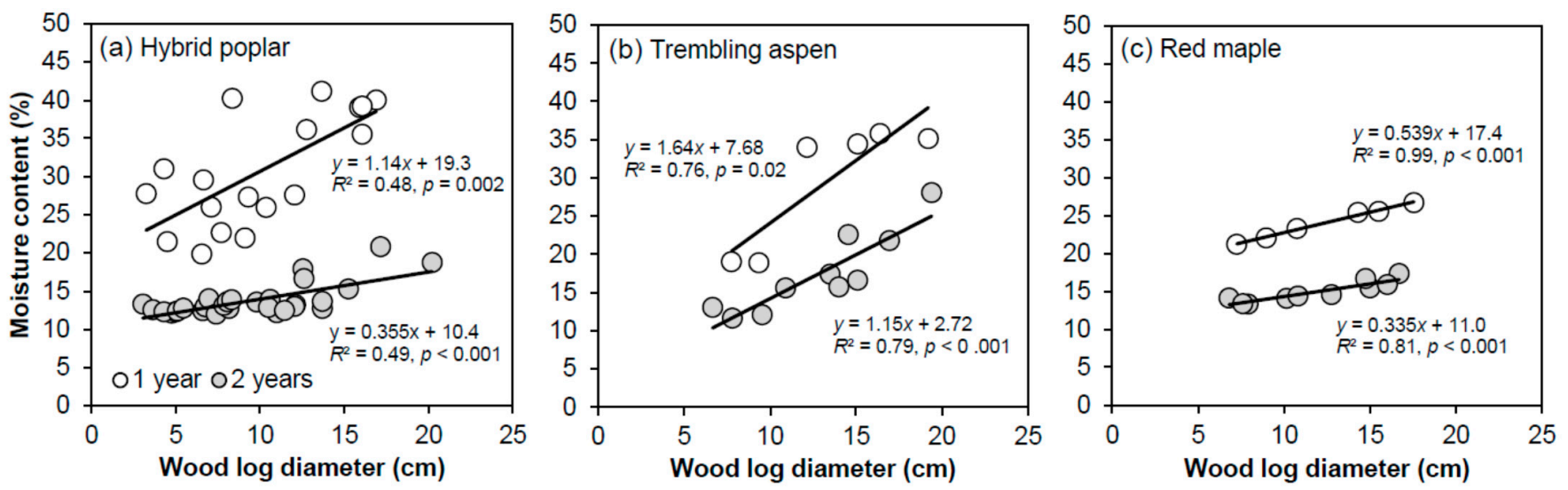

Figure 4. Linear relationships between the diameter of unsplit firewood logs (110 cm of length) and their moisture content after one year and two years of drying for: (a) hybrid poplar (genotype DN $\times$ M-915508); (b) trembling aspen; and (c) red maple. No significant relationship was found for white ash. For the one- and two-year relationships, respectively, $n=18$ and $n=30$ for poplar, and $n=6$ and $n=10$ for aspen and maple.

Chemical characteristics of freshly harvested and seasoned hybrid poplar firewood was also significantly affected by the diameter class (Table 2). A significant decline in N, $\mathrm{S}, \mathrm{P}$ and $\mathrm{Mg}$ concentrations was observed, with increasing diameter classes for freshly harvested logs and for the logs seasoned outdoors for one year (Table 2). Furthermore, the regression analyses showed significant non-linear trends (i.e., negative logarithmic relationships) between the above-mentioned variables (Figure 5). LHV showed a slight linear decline with increasing log diameter, but only for freshly harvested logs, as no significant effect of diameter was observed on LHV after one year of seasoning (Table 2, Figure 5a). Ca concentration increased with the diameter of freshly harvested logs, but not for seasoned logs (Table 2, Figure 5d). There was also a significant drying treatment effect for LHV $(p<0.001)$, with seasoned logs having slightly higher heating value than freshly harvested logs $(18.61 \mathrm{MJ} / \mathrm{kg}$ vs. $19.13 \mathrm{MJ} / \mathrm{kg})$. Such a trend was also observed for the C and Ca concentrations (Table 2). 
Table 2. Diameter class and drying treatment effects on chemical properties of unsplit hybrid poplar firewood logs (110 $\mathrm{cm}$ in length). S.E. $=$ standard error of the mean. $p$-values in bold denote a significant effect.

\begin{tabular}{|c|c|c|c|c|c|c|c|c|c|c|c|c|c|c|c|c|}
\hline \multirow[b]{2}{*}{$\begin{array}{c}\text { Diameter } \\
\text { Class }\end{array}$} & \multicolumn{2}{|c|}{$\begin{array}{l}\text { LHV }_{\text {dry }} \\
(\mathrm{MJ} / \mathrm{kg})\end{array}$} & \multicolumn{2}{|c|}{$C(\mathrm{~g} / \mathrm{kg})$} & \multicolumn{2}{|c|}{$\mathrm{N}(\mathrm{g} / \mathrm{kg})$} & \multicolumn{2}{|c|}{$S(g / k g)$} & \multicolumn{2}{|c|}{$P(g / k g)$} & \multicolumn{2}{|c|}{ K (g/kg) } & \multicolumn{2}{|c|}{$\mathrm{Ca}(\mathrm{g} / \mathrm{kg})$} & \multicolumn{2}{|c|}{$\mathrm{Mg}(\mathrm{g} / \mathrm{kg})$} \\
\hline & Fresh & 1 year & Fresh & 1 year & Fresh & 1 year & Fresh & 1 year & Fresh & 1 year & Fresh & 1 year & Fresh & 1 year & Fresh & 1 year \\
\hline $3.0-7.9 \mathrm{~cm}$ & 18.75 & 19.19 & 507.1 & 519.3 & 3.50 & 3.25 & 0.274 & 0.258 & 0.544 & 0.544 & 1.80 & 1.85 & 2.48 & 3.20 & 0.547 & 0.610 \\
\hline $8.0-12.9 \mathrm{~cm}$ & 18.62 & 19.19 & 512.5 & 521.3 & 2.46 & 2.15 & 0.187 & 0.173 & 0.398 & 0.358 & 1.85 & 1.75 & 2.67 & 3.13 & 0.481 & 0.486 \\
\hline$\geq 13 \mathrm{~cm}$ & 18.47 & 19.00 & 514.8 & 515.0 & 1.85 & 1.62 & 0.166 & 0.132 & 0.316 & 0.263 & 2.05 & 1.96 & 3.14 & 3.40 & 0.444 & 0.466 \\
\hline S.E. Class & 0.05 & 0.15 & 3.2 & 1.6 & 0.13 & 0.25 & 0.009 & 0.017 & 0.015 & 0.049 & 0.10 & 0.16 & 0.12 & 0.17 & 0.023 & 0.025 \\
\hline$p$-value Class & 0.002 & 0.60 & 0.24 & 0.04 & $<0.001$ & 0.001 & $<0.001$ & $<0.001$ & $<0.001$ & 0.003 & 0.21 & 0.69 & 0.005 & 0.54 & 0.02 & 0.002 \\
\hline Mean & 18.61 & 19.13 & 511.5 & 518.5 & 2.60 & 2.34 & 0.209 & 0.188 & 0.419 & 0.388 & 1.90 & 1.85 & 2.76 & 3.24 & 0.490 & 0.521 \\
\hline S.E. Drying & \multirow{2}{*}{\multicolumn{2}{|c|}{$\begin{array}{l}0.06 \\
<0.001\end{array}$}} & \multirow{2}{*}{\multicolumn{2}{|c|}{$\begin{array}{c}1.4 \\
\mathbf{0 . 0 0 2}\end{array}$}} & \multirow{2}{*}{\multicolumn{2}{|c|}{$\begin{array}{l}0.12 \\
0.12\end{array}$}} & \multicolumn{2}{|c|}{0.008} & \multicolumn{2}{|c|}{0.021} & \multicolumn{2}{|c|}{0.08} & \multicolumn{2}{|c|}{0.09} & \multicolumn{2}{|c|}{0.014} \\
\hline$p$-value Drying & & & & & & & 0. & & 0. & 77 & & 68 & $<0$ & & & \\
\hline $\begin{array}{c}p \text {-value } \\
\text { Class } \times \text { Drying }\end{array}$ & \multicolumn{2}{|c|}{0.82} & \multicolumn{2}{|c|}{0.06} & \multicolumn{2}{|c|}{0.98} & \multicolumn{2}{|c|}{0.46} & \multicolumn{2}{|c|}{0.61} & \multicolumn{2}{|c|}{0.82} & \multicolumn{2}{|c|}{0.32} & \multicolumn{2}{|c|}{0.47} \\
\hline
\end{tabular}
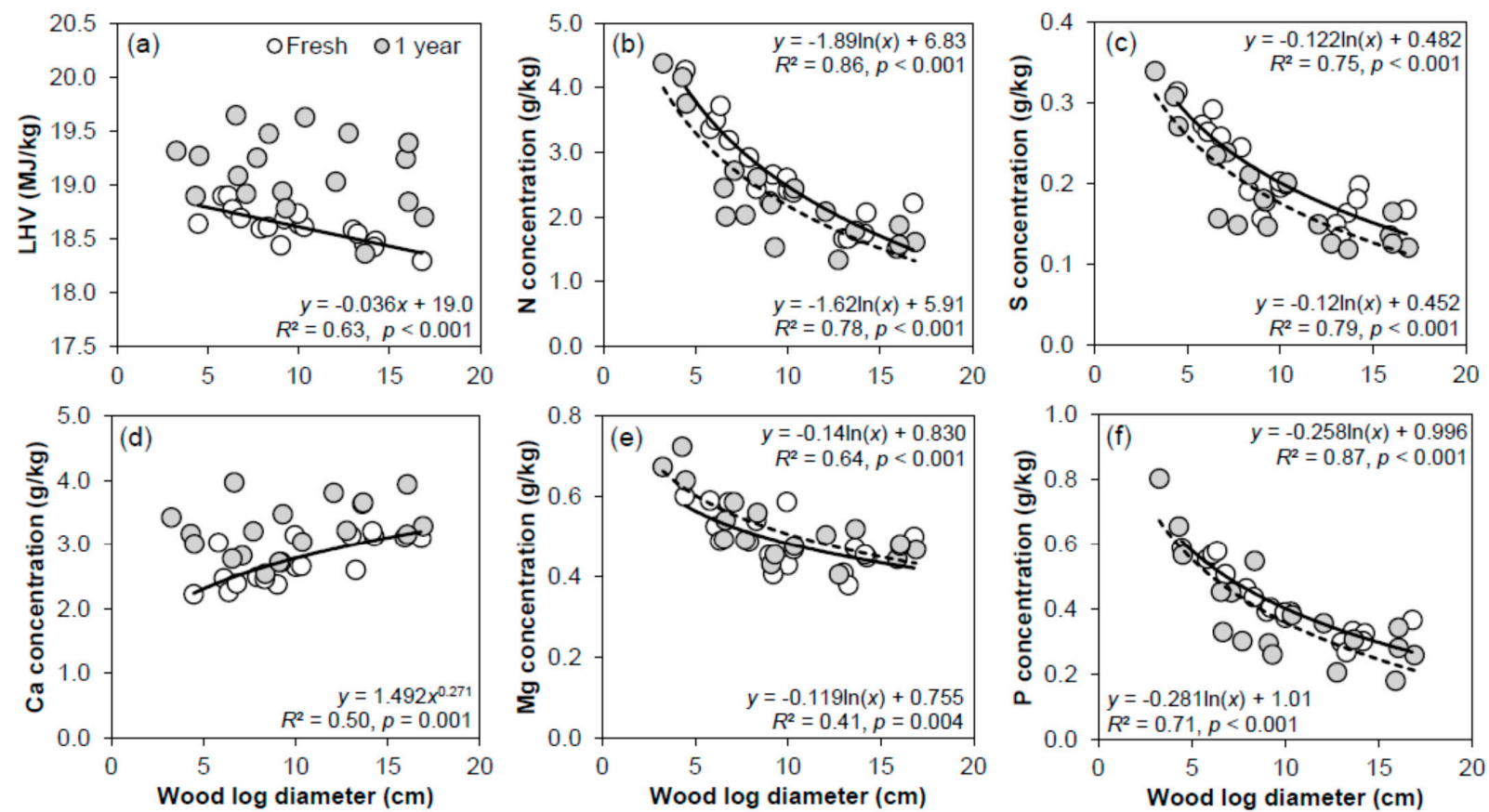

Figure 5. Relationships between hybrid poplar firewood log diameter (110 cm in length) and their (a) lower heating value $\left(\mathrm{LHV}_{\mathrm{dry}}\right)$ or $(\mathbf{b}-\mathbf{f})$ elemental concentration at harvest (Fresh, solid line) and after one year of drying outdoors (1 year, dashed line). $n=18$ for each relationship.

Results in Table 3 showed that LHV, C and N concentrations were similar for hybrid poplar, trembling aspen, red maple and white ash firewood, after one year of outdoor seasoning. White ash was the species with the highest $\mathrm{S}$ concentration, while $\mathrm{P}, \mathrm{K}, \mathrm{Ca}$ and $\mathrm{Mg}$ were more concentrated in hybrid poplar wood. $\mathrm{P}, \mathrm{K}$ and $\mathrm{Mg}$ concentrations of hybrid poplar firewood were almost two times higher than what was observed for trembling aspen (Table 3).

Table 3. Diameter and chemical properties ( \pm S.E. of the mean) of unsplit firewood logs $(110 \mathrm{~cm}$ in length). Means not connected with the same letter are significantly different $(\alpha=0.05$, Tukey's HSD test). $n=12$ for hybrid poplar and $n=6$ for the other species. $p$-values in bold denote a significant effect.

\begin{tabular}{|c|c|c|c|c|c|c|c|c|c|}
\hline Tree Species & Diameter (cm) & $\mathrm{LHV}_{\text {dry }}(\mathrm{MJ} / \mathrm{kg})$ & $\mathrm{C}(\mathrm{g} / \mathrm{kg})$ & $N(g / k g)$ & $S(g / k g)$ & $P(g / k g)$ & $\mathrm{K}(\mathrm{g} / \mathrm{kg})$ & $\mathrm{Ca}(\mathrm{g} / \mathrm{kg})$ & $\mathrm{Mg}(\mathrm{g} / \mathrm{kg})$ \\
\hline H. poplar & $12.3 \pm 1.1$ & $19.09 \pm 0.08$ & $518.1 \pm 1.2$ & $1.89 \pm 0.12$ & $0.153 \pm 0.008 b$ & $0.310 \pm 0.020 \mathrm{a}$ & $1.85 \pm 0.08 \mathrm{a}$ & $3.27 \pm 0.14 \mathrm{a}$ & $0.476 \pm 0.016 a$ \\
\hline $\begin{array}{l}\text { T. aspen } \\
\text { Then }\end{array}$ & $13.3 \pm 1.6$ & $18.92 \pm 0.12$ & $517.5 \pm 1.6$ & $1.65 \pm 0.18$ & $0.133 \pm 0.012 b$ & $0.167 \pm 0.029 \mathrm{~b}$ & $0.94 \pm 0.12 \mathrm{~b}$ & $3.14 \pm 0.19 a$ & $0.278 \pm 0.023 \mathrm{~b}$ \\
\hline R. maple & $12.4 \pm 1.6$ & $18.75 \pm 0.12$ & $520.3 \pm 1.6$ & $1.84 \pm 0.18$ & $0.139 \pm 0.012 \mathrm{~b}$ & $0.247 \pm 0.029 \mathrm{ab}$ & $1.08 \pm 0.12 b$ & $1.82 \pm 0.19 b$ & $0.193 \pm 0.023 \mathrm{~b}$ \\
\hline W. ash & $12.9 \pm 1.6$ & $18.88 \pm 0.12$ & $520.7 \pm 1.6$ & $1.94 \pm 0.18$ & $0.199 \pm 0.012 \mathrm{a}$ & $0.180 \pm 0.029 \mathrm{~b}$ & $1.73 \pm 0.12 \mathrm{a}$ & $2.63 \pm 0.19 \mathrm{a}$ & $0.252 \pm 0.023 b$ \\
\hline$p$-value & 0.96 & 0.12 & 0.40 & 0.64 & 0.002 & $<0.001$ & $<0.001$ & $<0.001$ & $<0.001$ \\
\hline
\end{tabular}




\subsection{Trial B}

The dry weight of selected logs for moisture content subsampling did not differ significantly between the cover treatments $(p=0.74)$, between the genotypes $(p=0.37)$ and between the genotype/cover treatment combinations $(p=0.89)$. For the short logs (40 cm of length) that were split on 22 May 2019, there was a significant cover treatment effect $(p<0.001)$ on moisture content measured five months later on 22 October 2019 (Figure 6a). Overall, covered logs had lower moisture content (17.3\%) than uncovered logs $(20.7 \%)$. There was a trend towards slightly higher moisture content $(p=0.11)$ for genotype $\mathrm{D} \times \mathrm{N}-3570$ than for genotype $\mathrm{M} \times \mathrm{B}-915311$ across the cover treatments. This trend was related to the presence of two extreme values for genotype $\mathrm{D} \times \mathrm{N}-3570$ in the uncovered treatment (Figure $6 \mathrm{~b}$ ). When those outliers were excluded from the ANOVA, the genotype and the interaction effects were far from significance $(p=0.51$ and $p=0.58$, respectively), while the cover treatment effect remained highly significant $(p<0.001)$.
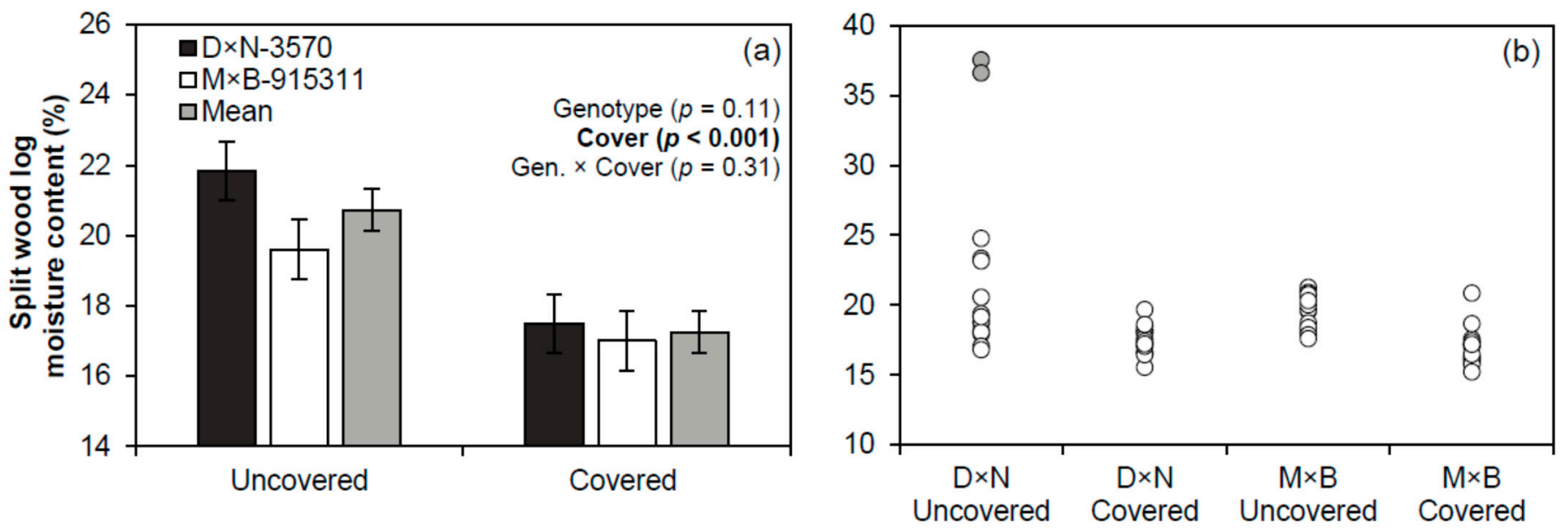

Figure 6. (a) Genotype and cover treatment effects on the final moisture content of split hybrid poplar firewood logs $(40 \mathrm{~cm}$ in length). Vertical bars represent the standard error of the mean; (b) Scatter plot of observations for moisture content of firewood logs for the different genotype/treatment combinations, with two outliers being represented by grey circles. For each genotype/treatment combination, 16 logs were sampled on 22 October 2019. Logs were split on 22 May 2019. Initial moisture content of harvested trees was statistically different between the genotypes $(p<0.001): 57.3 \pm 0.3 \%$ for genotype $\mathrm{D} \times \mathrm{N}-3570(n=20)$ and $58.9 \pm 0.3 \%$ for genotype $\mathrm{M} \times \mathrm{B}-915311(n=19)$.

\section{Discussion}

This study, conducted in a warm-summer humid continental climate, showed that hybrid poplar firewood harvested in the middle of the fall can reach satisfactory moisture content $( \pm 20 \%)$ for the next heating season, when it is split and processed in small logs (40 cm-long) in the spring. Covering the top of firewood cords with metal sheeting from the moment they were split (late May) significantly decreased the overall moisture content, from $20.7 \%$ down to $17.3 \%$ (Figure 4). Covering split logs was also important to reach a more homogeneous moisture content for genotype $\mathrm{D} \times \mathrm{N}-3570$ (Figure $6 \mathrm{~b}$ ). In the uncovered treatment, we observed moisture content of $36.5 \%$ and $37.5 \%$ for two logs of genotype $\mathrm{D} \times \mathrm{N}-3570$ that had a thick and furrowed bark. Such bark traits likely contributed to rewetting when logs are stacked bark side up, as we did. Conversely, the maximal moisture content observed for uncovered logs of genotype $\mathrm{M} \times \mathrm{B}-915311$, which has a smooth bark, was $21.3 \%$. Thus, if covering or roofing hybrid poplar logs just after splitting is not possible, it would be recommended to use smooth-barked genotypes to allow better percolation of rain water through the wood cords. Stacking logs bark side down is also an option that needs to be investigated with uncovered firewood from furrowed-barked genotypes. However, uncovered split logs piled bark side down generally regain more moisture during rainfall events compared to logs stacked bark side up [37]. In all cases, once logs are dry 
enough, split firewood should be stacked under a well-aerated shelter no later than October to prevent rewetting [18], which is a major issue for split poplar logs [38].

For the long unsplit logs (110 $\mathrm{cm}$ in length), a two-year cycle was necessary to produce firewood with satisfactory moisture content before the heating season (Figure 3). In our study, the second seasoning year took place in a well-aerated unheated warehouse (Table 1), which prevented wood rewetting for a whole year. One year of outdoor drying was clearly not enough to reach acceptable moisture content, even for the smaller diameter logs, although moisture content decreased substantially with log diameter (Figures 3 and 4). Such a trend was related to the fact that larger diameter logs dry more slowly [22], and tend to have a higher moisture content at harvest [39]. We also observed that moisture variation across the diameter classes was much larger after the first seasoning year than after the second year, as depicted by the slopes of regressions in Figure 4a. This reflects the convergence of wood drying curves with time, as wood log moisture content approaches the equilibrium point with ambient air [1,20].

In this case study, the abundant precipitation received during the summer of 2018 (Figure 2b) may have slowed log drying, with cumulative precipitations being negatively related to moisture content loss in unsplit hybrid poplar logs [21]. As an indication of the high moisture content of hybrid poplar logs during the first summer of seasoning, we observed abundant sprouts, which remained alive until August on the larger diameter logs (Figure 7). Conversely, two weeks after splitting and stacking the short hybrid poplar logs, no sprouting was observed, despite the fact that emerging sprouts were seen when the wood was split. This suggests high moisture content loss during the first weeks following splitting, as was also observed in other studies [20]. Moreover, important fungal colonization (mycelium and fruiting bodies) was observed on hybrid poplar logs from all diameter classes after outdoor seasoning (Figure 8), with moisture content of 30-50\% optimizing the growth of wood-decay fungi [16]. By causing mass loss of up to $6 \%$ per year on long unsplit poplar logs, fungal growth can substantially reduce the volumetric energy content of unsheltered poplar fuelwood [38]. Therefore, if long unsplit poplar logs cannot be sheltered after the first seasoning year, this firewood production avenue would not be recommended. Additional studies are also needed to evaluate to which extent splitting and covering or sheltering long logs from hybrid poplar would improve firewood quality and allow feedstock production on an annual cycle, thereby reducing by half the storage space needed. An investment of approximately \$ 3000 CAD would be needed to acquire a tractor-powered log splitter, which would be capable of processing logs of up to $120 \mathrm{~cm}$ in length [40].
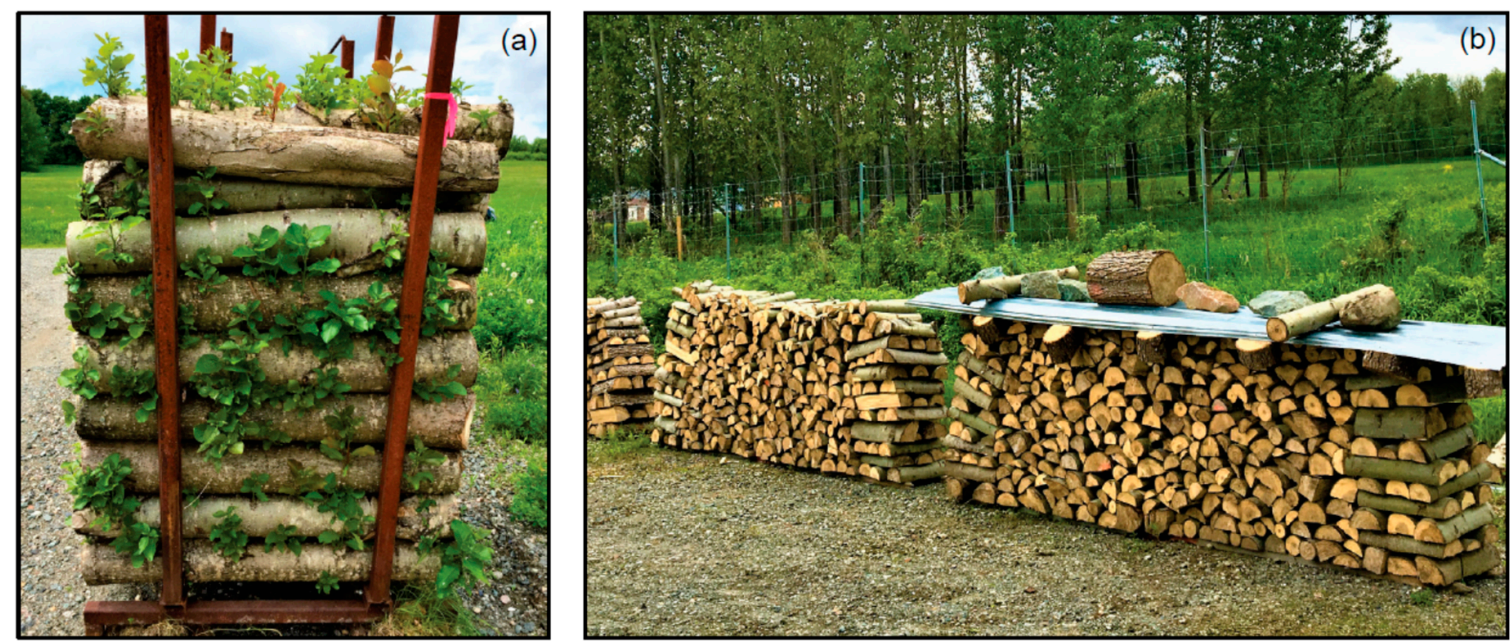

Figure 7. (a) On 7 June 2018, unsplit hybrid poplar logs had abundant sprouts, which remained alive until August on the larger diameter logs; and (b) on 4 June 2019, no sprouting was observed on short split logs that were processed on 22 May 2019. 

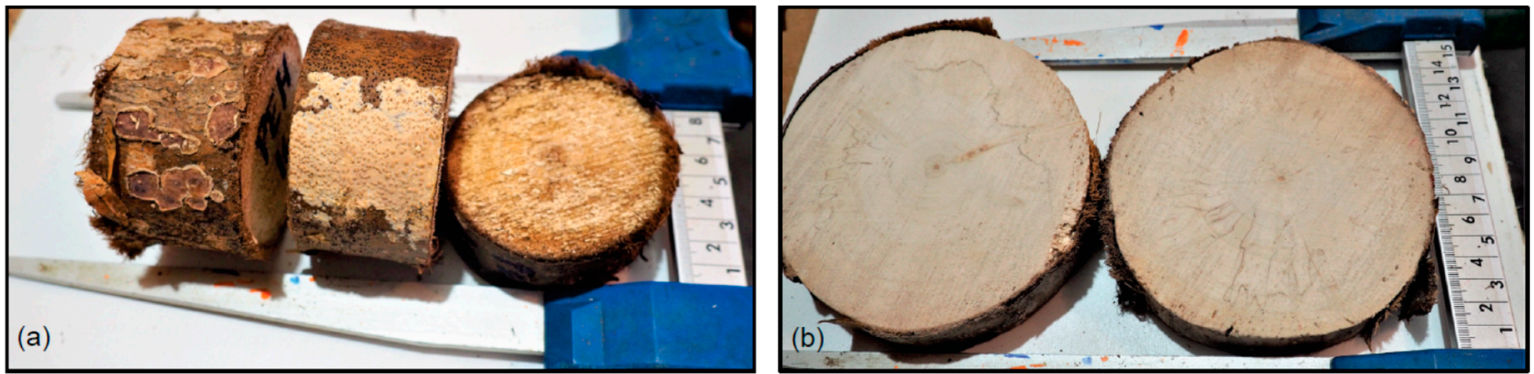

Figure 8. (a) Fruiting bodies; and (b) mycelium observed following fungal colonization of hybrid poplar logs (110 cm length) after one year of outdoor seasoning.

Among the four species tested, unsplit logs from hybrid poplar had the lowest moisture content after two years, despite the opposite trend being observed after one year (Figure $3 b$ ). Furthermore, although moisture content was not significantly different between hybrid poplar, trembling aspen and red maple, all these species had significantly lower moisture content than white ash after two years. Besides, at the end of the trial, log diameter was found to be a strong predictor of moisture content for all species, except for white ash (Figure 4). Thus, if splitting is not feasible with long logs, the use of smaller diameter pieces from species with a lower wood density (i.e., soft maples and poplars) would lead to greater net energy value on a mass basis, if we assume that LHV does not vary with $\log$ size following seasoning. Our results also showed that after two years, moisture content variations across the diameter range sampled were narrower for hybrid poplar than for trembling aspen, the larger logs of which had a moisture content of up to $28 \%$ (Figure $4 \mathrm{~b}$ ). This would be consistent with the fact that heartwood dries much more slowly than the sapwood in poplars [41], and that the proportion of heartwood in 7-year-old hybrid poplars is smaller than in slower growing forest-grown aspens of similar diameter.

After one year of seasoning, $\mathrm{N}$ concentration of hybrid poplar firewood showed a large decrease, with increasing log diameter (Table 2, Figure 5). Therefore, producing larger diameter logs in more widely spaced plantations could be a solution to minimize $\mathrm{N}$ oxides emissions by wood burning. On the other hand, the production of smaller diameter logs would provide feedstock with lower moisture content (Figure 3a) and higher net heating value. It would also allow more $\mathrm{N}$ and $\mathrm{P}$ to be exported from agricultural buffers (Table 2), which is of great importance to maintain the nutrient retention effectiveness of buffer strips in the long term [42]. Sulphur concentration in poplar firewood also largely declined with $\log$ diameter (Table 2, Figure 5). However, $\mathrm{S}$ concentrations reported in this study are well below the threshold values above which biomass $S$ causes concerns for air quality $(>2 \mathrm{~g} / \mathrm{kg})$ or appliance corrosion $(>1 \mathrm{~g} / \mathrm{kg}$ ) [25]. Additionally, after one year of seasoning, LHV and N concentration of hybrid poplar firewood was in the range of values observed for trembling aspen, red maple and white ash (Table 3). Conversely, P, K, Ca and Mg concentrations were the highest for hybrid poplar firewood, suggesting that its combustion may produce more ashes than the native species studied. Still, these conclusions are based on comparisons with a single hybrid poplar genotype, and do not reflect the wide genotypic variability in stem nutrient concentrations of hybrid poplars [9,28].

The LHV of freshly harvested hybrid poplar wood observed for genotype $\mathrm{DN} \times \mathrm{M}-915508$ across the three diameter classes $(18.61 \mathrm{MJ} / \mathrm{kg})$ was similar to values reported on a whole-stem basis for 8-year-old trees of genotype $\mathrm{D} \times \mathrm{N}-3570(18.65 \mathrm{MJ} / \mathrm{kg})$ and genotype $\mathrm{M} \times \mathrm{B}-915311$ (18.69 MJ $/ \mathrm{kg}$ ) grown at the same site [9]. This contrasts with the range of higher heating values observed between several genotypes in a short rotation coppice in Chile (17.7-20.8 MJ/kg) [43]. Interestingly, we observed a slight decline in the LHV of freshly harvested hybrid poplar logs with increasing diameter, a trend no longer significant after seasoning (Table 2, Figure 5a). At harvest, hybrid poplar branches also had slightly higher LHV compared to stem wood with bark [9]. More elevated heating values 
in smaller diameter woody tissues may be related to their higher content in energy-rich extractives, as observed in Liriodendron tulipifera L. [44]. Overall, the heating value of hybrid poplar logs also increased by $2.8 \%$ following the one-year seasoning period outdoors. However, we did not measure if this increasing trend in LHV occurred after the second seasoning year. Following seasoning, both increases and decreases in energy values have been reported for different woody biomass fuels $[16,45]$. The volatilization and oxidation of wood extractives reduce the heating value, while the opposite trend occurs following the preferential biological degradation of carbohydrate polymers, as this process increases the lignin concentration of woody biomass [16]. As in other studies [24,46], we observed a significant increase (of $1.4 \%$ ) in the C concentration of poplar fuelwood following seasoning, which is consistent with the increase in the LHV observed (Table 2).

At harvest, Ca concentration slightly increased with poplar log diameter, which contrasted with the trend observed for other macronutrients (Figure 5). In another study, Ca concentration in young hybrid aspens ( $P$. tremula $\times P$. tremuloides) was found to be fairly constant along the stem [47]. Surprisingly, the diameter effect on Ca concentration was no longer significant following the seasoning period, and seasoned hybrid poplar firewood had a higher Ca concentration (Table 2). Mass loss during seasoning could have led to such an increase in Ca concentration, although the opposite trend was observed for $\mathrm{S}$ concentration. Different and interacting factors likely contribute to the changes observed in element concentration following seasoning, including mass loss, nutrient loss from sprouting, nutrient leaching induced by precipitation, fungal growth and endophyte activity.

Finally, we may have slightly underestimated the moisture content of firewood as moisture content was measured after oven-drying samples at $95^{\circ} \mathrm{C}$, and not at $105^{\circ} \mathrm{C}$, which is preferable [48]. Moreover, we sampled very few individuals for each native woodlot species, as the focus of this study was hybrid poplar. Thus, conclusions regarding hybrid poplar comparisons with other species are limited by this low sampling effort. Some operational aspects could also be improved. In both trials, we harvested wood in early November. However, because little drying occurs during the fall and winter months, harvesting firewood in late winter or early spring is recommended [18]. Softwood species like Norway spruce (Picea abies K.) can even be harvested in early June and be ready for the heating season, when small split logs are properly sheltered. Harvesting poplars in late spring with their foliage may also accelerate stem moisture loss through transpirational drying [16], while maximizing nutrient exportation from agricultural buffers [49]. On the other hand, if heavy machinery is used, a frozen-ground harvest would be preferable to maintain the integrity of buffer soils and reduce sediment inputs to streams [50].

\section{Conclusions}

This study, done in a warm-summer humid continental climate, showed that hybrid poplar firewood of satisfactory quality can be produced on a yearly cycle for short split logs and on a biannual cycle for long unsplit logs. Covering split logs was important to lower moisture content and reduce its variability. For the long unsplit poplar logs, moisture content and element concentrations showed opposite trends in relation to log diameter, with larger logs containing fewer mineral elements, but higher moisture content and thus lower net heating value. Based on wood elemental composition, we found little evidence that the use of hybrid poplar firewood would be more problematic than the use of firewood produced with native tree species, except that it may generate more ashes given its high $\mathrm{P}$ and base cation content. Given the rapid combustion of the low-density poplar wood, this feedstock would be especially suited for heating in the fall and in the spring, when the heat demand is lower than during cold winter months. The large-scale implementation of high-yielding bioenergy buffers could improve ecosystem services provision on farmland (C sequestration, non-point source pollution control, hydrological regulation, increase forest habitat connectivity), while reducing the firewood harvesting pressure in natural forest habitats. This could create opportunities for forest habitat conservation in agriculturedominated landscapes. 
Author Contributions: Conceptualization, J.F., B.T. and D.G.; Methodology, J.F. and B.T.; Formal Analysis, J.F.; Investigation, J.F. and B.T.; Data Curation, J.F.; Writing-Original Draft Preparation, J.F.; Writing-Review \& Editing, B.T., D.G. and F.L.; Visualization, J.F.; Project Administration, F.L. and B.T.; Funding Acquisition, B.T., D.G., F.L. and J.F. All authors have read and agreed to the published version of the manuscript.

Funding: This research and the APC were funded by Agriculture and Agri-food Canada, Canada (AGGP2-001) (Agricultural Greenhouse Gas Program).

Data Availability Statement: The data presented in this study are available on request from the corresponding author.

Acknowledgments: We are grateful to the Benedictine Community of St-Benoît-du-Lac for having allowed this project to be carried out on their property. We thank Agriculture and Agri-food Canada, Canada (AGGP2-001) (Agricultural Greenhouse Gas Program), Natural Resources Canada, the Ministère des Forêts, de la Faune et des Parcs du Québec (Chantier sur la Forêt Feuillue program) and CRÉ-Estrie (Volet 2 program), as well as Tree Canada, for the funding received. R. Pouliot and O. Srdjan (ISFORT, UQO, Ripon, QC, Canada) and the staff from the CTRI (Rouyn-Noranda, QC, Canada) are thanked for the chemical analyses of wood samples. Finally, we wish to thank tree planters and field assistants (O. Dubuc, J.D. Careau, L. Godbout, Brother L. Lamontagne, Y. Lauzière, J. Lemelin, M.A. Pétrin), as well as the Berthier Nursery (MFFP) for the planting stocks.

Conflicts of Interest: The authors declare no conflict of interest.

\section{References}

1. Manzone, M. Energy and moisture losses during poplar and black locust logwood storage. Fuel Process. Technol. 2015, 138, 194-201. [CrossRef]

2. Côté, M.-A.; Gilbert, D.; Nadeau, S. Characterizing the profiles, motivations and behaviour of Quebec's forest owners. For. Policy Econ. 2015, 59, 83-90. [CrossRef]

3. Doornbos, J.; Richardson, J.; van Oosten, C. Activities related to poplar and willow cultivation and utilization in Canada. In Canadian Report to the 25th Session of the International Poplar Commission; Poplar and Willow Council of Canada: Edmonton, AB, Canada, 2016.

4. $\quad$ Butler, B.J.; Hewes, J.H.; Dickinson, B.J.; Andrejczyk, K.; Butler, S.M.; Markowski-Lindsay, M. Family forest ownerships of the united states, 2013: Findings from the USDA Forest Service's national woodland owner survey. J. For. 2016, 114, 638-647. [CrossRef]

5. Jobin, B.; Latendresse, C.; Baril, A.; Maisonneuve, C.; Boutin, C.; Côté, D. A half-century analysis of landscape dynamics in southern Québec, Canada. Environ. Monit. Assess. 2014, 186, 2215-2229. [CrossRef] [PubMed]

6. Kaushal, S.S.; Mayer, P.M.; Vidon, P.G.; Smith, R.M.; Pennino, M.J.; Newcomer, T.A.; Duan, S.; Welty, C.; Belt, K.T. Land use and climate variability amplify carbon, nutrient, and contaminant pulses: A review with management implications. JAWRA 2014, 50, 585-614. [CrossRef]

7. Schoeneberger, M.M.; Bentrup, G.; Patel-Weynand, T. Agroforestry: Enhancing Resiliency in U.S. Agricultural Landscapes under Changing Conditions; U.S. Department of Agriculture, Forest Service: Washington, DC, USA, 2017; p. 228.

8. Fortier, J.; Truax, B.; Gagnon, D.; Lambert, F. Soil nutrient availability and microclimate are influenced more by genotype than by planting stock type in hybrid poplar bioenergy buffers on farmland. Ecol. Engin. 2020, 157, 105995. [CrossRef]

9. Truax, B.; Fortier, J.; Gagnon, D.; Lambert, F. Long-term effects of white-tailed deer overabundance, hybrid poplar genotype and planting stock type on tree growth and ecosystem services provision in bioenergy buffers. For. Ecol. Manag. 2021, $480,118673$. [CrossRef]

10. Ferrarini, A.; Serra, P.; Almagro, M.; Trevisan, M.; Amaducci, S. Multiple ecosystem services provision and biomass logistics management in bioenergy buffers: A state-of-the-art review. Renew. Sustain. Energy Rev. 2017, 73, 277-290. [CrossRef]

11. Fortier, J.; Truax, B.; Gagnon, D.; Lambert, F. Potential for hybrid poplar riparian buffers to provide ecosystem services in three watersheds with contrasting agricultural land use. Forests 2016, 7, 37. [CrossRef]

12. Schultz, R.C.; Isenhart, T.M.; Simpkins, W.W.; Colletti, J.P. Riparian forest buffers in agroecosystems-lessons learned from the Bear Creek Watershed, central Iowa, USA. Agrofor. Syst. 2004, 61-62, 35-50.

13. Truax, B.; Gagnon, D.; Lambert, F.; Fortier, J. Multiple-use zoning model for private forest owners in agricultural landscapes: A case study. Forests 2015, 6, 3614-3664. [CrossRef]

14. Fortier, J.; Truax, B.; Gagnon, D.; Lambert, F. Mature hybrid poplar riparian buffers along farm streams produce high yields in response to soil fertility assessed using three methods. Sustainability 2013, 5, 1893-1916. [CrossRef]

15. Truax, B.; Gagnon, D.; Fortier, J.; Lambert, F. Biomass and volume yield in mature hybrid poplar plantations on temperate abandoned farmland. Forests 2014, 5, 3107-3130. [CrossRef]

16. Krigstin, S.; Wetzel, S. A review of mechanisms responsible for changes to stored woody biomass fuels. Fuel 2016, 175, 75-86. [CrossRef] 
17. Dzurenda, L.; Banski, A. The effect of firewood moisture content on the atmospheric thermal load by flue gases emitted by a boiler. Sustainability 2019, 11, 284. [CrossRef]

18. Nord-Larsen, T.; Bergstedt, A.; Farver, O.; Heding, N. Drying of firewood-the effect of harvesting time, tree species and shelter of stacked wood. Biomass Bioenergy 2011, 35, 2993-2998. [CrossRef]

19. United State Environmental Protection Agency. Burn Wise. Available online: https://www.epa.gov/burnwise (accessed on 9 November 2020).

20. Manzone, M. Performance evaluation of different techniques for firewood storage in Southern Europe. Biomass Bioenergy 2018, 119, 22-30. [CrossRef]

21. Kim, D.-W.; Murphy, G. Forecasting air-drying rates of small Douglas-fir and hybrid poplar stacked logs in Oregon, USA. Int. J. For. Eng. 2013, 24, 137-147. [CrossRef]

22. Visser, R.; Berkett, H.; Spinelli, R. Determining the effect of storage conditions on the natural drying of radiata pine logs for energy use. N. Z. J. For. Sci. 2014, 44, 3. [CrossRef]

23. Röser, D.; Mola-Yudego, B.; Sikanen, L.; Prinz, R.; Gritten, D.; Emer, B.; Väätäinen, K.; Erkkilä, A. Natural drying treatments during seasonal storage of wood for bioenergy in different European locations. Biomass Bioenergy 2011, 35, 4238-4247. [CrossRef]

24. Lee, J.S.; Sokhansanj, S.; Lau, A.K.; Lim, C.J.; Bi, X.T.; Basset, V.; Yazdanpanah, F.; Melin, S.O. The effects of storage on the net calorific value of wood pellets. Can. Biosyst. Eng. 2015, 57, 5-12. [CrossRef]

25. Obernberger, I.; Brunner, T.; Bärnthaler, G. Chemical properties of solid biofuels—Significance and impact. Biomass Bioenergy 2006, 30, 973-982. [CrossRef]

26. Ravishankara, A.R.; Daniel, J.S.; Portmann, R.W. Nitrous oxide $\left(\mathrm{N}_{2} \mathrm{O}\right)$ : The dominant ozone-depleting substance emitted in the 21st century. Science 2009, 326, 123. [CrossRef] [PubMed]

27. Heil, J.; Vereecken, H.; Brüggemann, N. A review of chemical reactions of nitrification intermediates and their role in nitrogen cycling and nitrogen trace gas formation in soil. Eur. J. Soil Sc. 2016, 67, 23-39.

28. Rodríguez-Soalleiro, R.; Eimil-Fraga, C.; Gómez-García, E.; García-Villabrille, J.D.; Rojo-Alboreca, A.; Muñoz, F.; Oliveira, N.; Sixto, H.; Pérez-Cruzado, C. Exploring the factors affecting carbon and nutrient concentrations in tree biomass components in natural forests, forest plantations and short rotation forestry. For. Ecosyst. 2018, 5, 35. [CrossRef]

29. Augusto, L.; Meredieu, C.; Bert, D.; Trichet, P.; Porté, A.; Bosc, A.; Lagane, F.; Loustau, D.; Pellerin, S.; Danjon, F.; et al. Improving models of forest nutrient export with equations that predict the nutrient concentration of tree compartments. Ann. For. Sci. 2008, 65,808 .

30. Robitaille, A.; Saucier, J.-P. Paysages Régionaux du Québec Méridional; Les Publications du Québec: Ste-Foy, QC, Canada, 1998; p. 213.

31. Government of Canada. Station Results-1981-2010. Climate Normals and Averages. Available online: http:// climate.weather. gc.ca/climate_normals/station_select_1981_2010_e.html?searchType=stnProv\&lstProvince=QC (accessed on 11 May 2020).

32. Government of Canada. Historical Climate Data. Available online: https:/ / climate.weather.gc.ca/index_e.html (accessed on 11 May 2020).

33. Manikandan, S. Data transformation. J. Pharm. Pharm. 2010, 1, 126-127. [CrossRef]

34. Petersen, R.G. Use and misuse of multiple comparison procedures. Agron. J. 1977, 69, 205-208. [CrossRef]

35. Royston, P. An extension of Shapiro and Wilk's W test for normality to large samples. Appl. Stat. 1982, 31, 115-124. [CrossRef]

36. Chambers, J.M.; Cleveland, W.S.; Kleiner, B.; Tukey, P.A. Graphical Methods for Data Analysis; Wadsworth International Group: Belmont, CA, USA, 1983.

37. Spartz, J.T. A Hot Debate: Stacking Firewood Bark Up or Bark Down? Lab Note. News from the Forest Products Laboratory. USDA Forests Service. Available online: https://www.fpl.fs.fed.us/labnotes/?p=436\#: \{\}:text=If\%20split $\% 20$ wood $\% 20$ is $\% 20$ stored, and \%20accelerate $\% 20$ decay $\% 2$ C $\%$ 20says $\% 20$ Knaebe (accessed on 19 January 2021).

38. Erber, G.; Huber, C.; Stampfer, K. To split or not to split: Feasibility of pre-storage splitting of large poplar (Populus spp. L.) fuelwood logs. Fuel 2018, 220, 817-825. [CrossRef]

39. Fortier, J.; Truax, B.; Gagnon, D.; Lambert, F. Allometric equations for estimating compartment biomass and stem volume in mature hybrid poplars: General or site-specific? Forests 2017, 8, 309. [CrossRef]

40. Wallenstein Equipment Inc. Splitter Model WX330 Horizontal Tractor. Available online: https:/ / www.wallensteinequipment. $\mathrm{com} / \mathrm{ca} / \mathrm{en} / \mathrm{model} / \mathrm{wx} 330$ (accessed on 15 January 2021).

41. Balatinecz, J.; Mertens, P.; de Boever, L.; Yukun, H.; Jin, J.; van Acker, J. 10 Properties, processing and utilization. In Poplar and Willows: Tree for the Society and the Environment; Isebrands, J.G., Richardson, J., Eds.; CAB Interantional and FAO: Rome, Italy, 2014; pp. 527-561.

42. Stutter, M.; Kronvang, B.; Ó hUallacháin, D.; Rozemeijer, J. Current insights into the effectiveness of riparian management, attainment of multiple benefits, and potential technical enhancements. J. Environ. Qual. 2019, 48, 236-247. [CrossRef] [PubMed]

43. Carmona, R.; Nuñez, T.; Alonso, M.F. Biomass yield and quality of an energy dedicated crop of poplar (Populus spp.) clones in the Mediterranean zone of Chile. Biomass Bioenergy 2015, 74, 96-102. [CrossRef]

44. Myeong, S.-J.; Han, S.-H.; Shin, S.-J. Analysis of chemical compositions and energy contents of different parts of yellow poplar for development of bioenergy technology. J. Korean For. Soc. 2010, 99, 706-710.

45. Therasme, O.; Eisenbies, M.H.; Volk, T.A. Overhead protection increases fuel quality and natural drying of leaf-on woody biomass storage piles. Forests 2019, 10, 390. [CrossRef] 
46. Nurmi, J. The storage of logging residue for fuel. Biomass Bioenergy 1999, 17, 41-47. [CrossRef]

47. Rytter, L. Nutrient content in stems of hybrid aspen as affected by tree age and tree size, and nutrient removal with harvest. Biomass Bioenergy 2002, 23, 13-25. [CrossRef]

48. Matthews, S. Effect of drying temperature on fuel moisture content measurements. Int. J. Wildland Fire 2010, 19, 800-802. [CrossRef]

49. Fortier, J.; Gagnon, D.; Truax, B.; Lambert, F. Nutrient accumulation and carbon sequestration in 6 year-old hybrid poplars in multiclonal agricultural riparian buffer strips. Agric. Ecosyst. Environ. 2010, 137, 276-287. [CrossRef]

50. Rashin, E.B.; Clishe, C.J.; Loch, A.T.; Bell, J.M. Effectiveness of timber harvest practices for controlling sediment related water quality impacts. JAWRA 2006, 42, 1307-1327. [CrossRef] 